\title{
Callus Initiation and Regeneration in Mentha
}

\section{J.M. Van Eck ${ }^{1}$ and S.L. Kitto ${ }^{2}$ \\ Delaware Agricultural Experiment Station, Department of Plant Science, College of Agricultural Sciences, University of Delaware, Newark, DE 19717-1303}

\section{Additional index words. mint, Labiatae, tissue culture, organogenesis}

\begin{abstract}
Plant regeneration from callus cultures of mint depended on expiant source, genotype, and culture medium components. Mature embryos, seedling and flower parts, as well as chilled or desiccated immature embryos of peppermint (Mentha piperita L.) and spearmint (Mentha spicata L.) were cultured on a Murashige-Skoog medium containing various combinations of growth factors. Shoots regenerated from callus that developed either on mature peppermint embryos cultured on medium that contained BA at $0.5 \mathrm{mg} \cdot \mathrm{liter}^{-1}$ and $\mathrm{NAA}$ at $0.5 \mathrm{mg} \cdot \operatorname{liter}^{-1}$ or on immature peppermint embryos (chilled at SC for 0.6 day or nonchilled) cultured on basal medium containing BA at

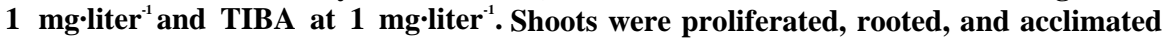
with $100 \%$ survival under greenhouse conditions. Chemical names used: $N$-(phenylmethyl) -1H-purin-6-amine (BA); 1-naphthaleneacetic acid (NAA); 2,3,5-triiodobenzoic acid (TIBA).
\end{abstract}

Mints are valued in the United States for their essential oils, which had a value of about \$74 million in 1986 (Green, 1987). Both essential oil quality and quantity are' reduced by pests associated with mint cultivation (Green, 1985). Because of mints'- sterility, improvement of their tolerance or resistance to pests is not possible using conventional breeding techniques. However, variation generated by use of tissue culture regeneration techniques has resulted in improvement of diverse commercial crops (Reisch, 1983). The objective of this research was to establish protocols for regeneration of peppermint and spearmint. Explant source and medium components were examined to detemine their influence on shoot regeneration from these species.

Explant source included seedling parts (cotyledons, hypocotyls, roots), flower parts (petals, anthers, ovaries, stigmas), and mature and immature embryos from peppermint and spearmint. After surface disinfecting as described below, seeds were scarified and either cultured (mature embryo source) or germinated 'sterilely on moist filter paper. Flower parts were excised from peppermint flower buds just beginning to show color.

Received for publication 22 Feb. 1989. Published as a miscellaneous Paper no. 1259 of the Delaware Agricultural Experiment Station, Dept. of Plant Science, College of Agricultural Sciences, Univ. of Delaware, Newark. Mention of trade names in this publication does not imply endorsement by the Delaware Agricultural Experiment Station of products named, nor criticism of similar ones not named. The cost of publishing this paper was defrayed in part by the payment of page charges. Under postal regulations, this paper therefore must be hereby marked advertisement solely to indicate this fact.

'Former Research Assistant. Currently Research Assistant, Dept. of Plant Breeding, Cornell Univ., Ithaca, NY 14853.

${ }^{2}$ Assistant Professor.
Immature embryos of defined ages were obtained by tagging peppermint flower clusters when 1) the first flower opened, or one day after anthesis (DAA), and 2) the last flower opened. Fruits (a fruit includes four nutlets plus exocarp) were collected 10 to $28 \mathrm{DAA}$ and were pretreated either by chilling at 5C for $0,0.6,1,2,4,5$, or 7 days or by desiccating at room temperature $(23 \mathrm{C})$ for $0,0.6$, $2,4,5$, or 7 days.

To obtain axenic mature embryo and seedling explants, seeds were soaked overnight in distilled water and then were treated 1.5 $\min$ in $70 \%(\mathrm{v} / \mathrm{v})$ ethanol. Seeds, flower buds, and fruits were surface-disinfected for $20 \mathrm{~min}$ in a $20 \%(\mathrm{v} / \mathrm{v})$ commercial bleach $[5.25 \%$ (w/v) sodium hypochlorite] plus $0.1 \%(\mathrm{v} / \mathrm{v})$ Tween-20 solution and rinsed three times with sterile deionized water.

Basal medium consisted of Murashige and Skoog (1962) (MS) salts and vitamins, sucrose at $20 \mathrm{~g} \cdot 1$ iter $^{-1}$ and washed Difco Bacto agar at $10 \mathrm{~g} \cdot$ liter $^{-1}$. The following addenda were examined: 2,4-D; NAA; BA; zeatin; TIBA; coconut water $(\mathrm{CW})$; and adenine sulfate. The $\mathrm{pH}$ of all media was adjusted to 5.7 to 5.8 before autoclaving for $15 \mathrm{~min}$ at $121 \mathrm{C}$ and $124 \mathrm{kPa}$.

There were five explants cultured per 60 $\times 15-\mathrm{mm}$ petri dish containing $10 \mathrm{ml}$ of medium, except when noted otherwise. Each treatment contained 1 to 25 petri dishes in a completely randomized design. Cultures were subculture every 30 days, except when noted, onto the same medium and maintained in darkness at $25 \pm 2 \mathrm{C}$ for 60 days. Cultures were then placed under cool-white fluorescent lamps at $10 \mu \mathrm{mol} \cdot \mathrm{s}^{-1} \cdot \mathrm{m}^{-2}$ of photosynthetically active radiation (PAR) with a 16hr photoperiod.

After 2 weeks under lights, regenerants were separated and placed on proliferation medium of MS salts and vitamins and the following addenda per liter: sucrose, $30 \mathrm{~g}$; BA, $1 \mathrm{mg}$; and washed Difco Bacto agar, 6
Table 1. Effect of NAA and BA on callus initiation and shoot regeneration by mature embryos of peppermint and spearmint.

\begin{tabular}{lclr}
\hline \hline & & \multicolumn{2}{c}{ Callus $^{2}(\%)$} \\
\cline { 3 - 4 } Mint type & $\begin{array}{c}\text { NAA } \\
(\mathrm{mg} \cdot \text { liter-1) }\end{array}$ & 0.5 & 1 \\
\hline Peppermint & 0.5 & $65^{y}$ & 50 \\
Spearmint & 1 & 60 & 70 \\
& 0.5 & 80 & 85 \\
& 1 & 50 & 70 \\
\hline
\end{tabular}

${ }^{2}$ Percent of mature embryos $(n=20)$ with callus; none was produced when both growth regulators were lacking.

${ }^{y}$ Two calli regenerated five shoots each.

g. Shoots were proliferated under cool-white fluorescent lamps at $60 \mu \mathrm{mol} \cdot \mathrm{s}^{-1} \cdot \mathrm{m}^{-2}$ of PAR with a 16-hr photoperiod.

Thirty cuttings each from 8-week-old proliferating shoots were rooted in 601 Sutton market packs $(12.5 \times 16.5 \times 5.5 \mathrm{~cm})($ Cord Products, East Brampton, Ontario) containing Redi-Earth peat-lite soilless mix (W.R. Grace, Fogelsville, Pa.). Market packs were maintained in clear plastic trays in the laboratory for 2 weeks under $60 \mu \mathrm{mol} \cdot \mathrm{s}^{-1} \cdot \mathrm{m}^{-2}$, placed under intermittent mist in the greenhouse for 2 weeks, and then transferred to a greenhouse bench.

In a preliminary experiment, cotyledons, hypocotyls, and roots from peppermint were cultured on basal medium supplemented with $150 \mathrm{ml} \mathrm{CW} /$ liter and 2,4-D $(0.5,1.0$ $\mathrm{mg} \cdot$ liter $^{-1}$, and subculture every 2 or 4 weeks. Subculture times did not affect callus initiation or growth; therefore, cultures were subculture every 4 weeks.

Seeds containing mature embryos of peppermint and spearmint were cultured on basal medium containing NAA $(0,0.5,1$ $\mathrm{mg} \cdot$ liter $\left.^{-1}\right)$ and BA $\left(0,0.5,1 \mathrm{mg} \cdot\right.$ liter $\left.^{-1}\right)$. Embryos initiated callus on medium containing both growth regulators (Table 1) but not on medium lacking both growth regulators (data not shown). Cream-colored, compact peppermint calli regenerated shoots on medium containing $0.5 \mathrm{mg} \mathrm{BA}$ and $0.5 \mathrm{mg} \mathrm{NAA} /$ liter. Shoots proliferated, rooted, and acclimated to greenhouse conditions, where survival was $100 \%$. Mature embryos cultured on basal medium supplemented only with NAA $\left(0,0.5,1,2,4 \mathrm{mg} \cdot\right.$ liter $\left.^{-1}\right)$ produced nonregenerative callus (data not shown)

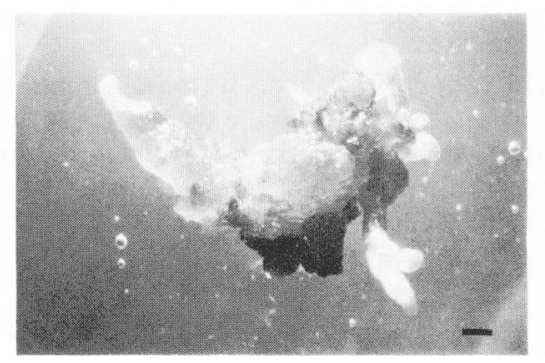

Fig. 1. Shoots regenerating from callus of a nonchilled, 15 to $25 \mathrm{DAA}$ peppermint immature embryo. $($ Bar $=1 \mathrm{~mm}$.) 
Table 2. Effect of BA and 2,4-D on callus initiation from various plant parts of peppermint and spearmint.

\begin{tabular}{|c|c|c|c|c|c|c|}
\hline \multirow[b]{3}{*}{ Mint type } & \multirow[b]{3}{*}{$\left(\mathrm{mg} \cdot\right.$ liter $\left.^{-1}\right)$} & \multicolumn{5}{|c|}{ Callus $^{\text {z,y }}(\%)$} \\
\hline & & \multicolumn{5}{|c|}{ 2,4-D (mg.liter $\left.{ }^{-1}\right)$} \\
\hline & & 0 & 0.5 & 2 & 5 & 10 \\
\hline & \multicolumn{6}{|c|}{ Petals } \\
\hline \multirow[t]{30}{*}{ Peppermint } & 0 & $0 *$ & $100(+)$ & $80(+)$ & 20 & 20 \\
\hline & 0.5 & 0 & 100 & 47 & 100 & 80 \\
\hline & 2 & 0 & $80(+)$ & 47 & 100 & 80 \\
\hline & 5 & 0 & 100 & 47 & 100 & $47(+)$ \\
\hline & 10 & 0 & 80 & 67 & 100 & 80 \\
\hline & $\begin{array}{l}0 \\
0.5 \\
2 \\
5 \\
10\end{array}$ & $\begin{array}{c}100 * \\
0 \\
0 \\
0 \\
0\end{array}$ & $\begin{array}{ll} & \text { Ova } \\
80(+) & \\
0 & \\
47 & \\
20 & \\
67 & \end{array}$ & $\begin{array}{l}20(+) \\
80 \\
47 \\
33 \\
47\end{array}$ & $\begin{array}{r}20 \\
67 \\
67 \\
67 \\
0\end{array}$ & $\begin{array}{r}20 \\
0 \\
0 \\
20 \\
0\end{array}$ \\
\hline & \multicolumn{6}{|c|}{ Anthers } \\
\hline & 0 & $0 *$ & 33 & 0 & 20 & 0 \\
\hline & 0.5 & 0 & 20 & 20 & 0 & 47 \\
\hline & 2 & 0 & 47 & 20 & 33 & 100 \\
\hline & 5 & 0 & 0 & 0 & 0 & 0 \\
\hline & 10 & 0 & 47 & 20 & 0 & 20 \\
\hline & \multicolumn{6}{|c|}{ Stigmas } \\
\hline & 0 & $0^{*}$ & 0 & 0 & $20(+)$ & 0 \\
\hline & 0.5 & 0 & 0 & 0 & 0 & 0 \\
\hline & 2 & 0 & 0 & 0 & 47 & 0 \\
\hline & 5 & 0 & 0 & 0 & 0 & 0 \\
\hline & 10 & 0 & 0 & 0 & 100 & 0 \\
\hline & \multicolumn{6}{|c|}{ Mature embryos } \\
\hline & 0 & 0 & 20 & $40(+)$ & $60(+)$ & $60(+)$ \\
\hline & 0.5 & 0 & 0 & $60(+)$ & $80(+)$ & $60(+)$ \\
\hline & 2 & 0 & $60(+)$ & $100(+)$ & $80(+)$ & $100(+)$ \\
\hline & 5 & 0 & $40(+)$ & $60(+)$ & $80(+)$ & $60(+)$ \\
\hline & 10 & $80(+)$ & $60(+)$ & $40(+)$ & $60(+)$ & $60(+)$ \\
\hline & \multicolumn{6}{|c|}{ Cotyledons } \\
\hline & 0 & 0 & 0 & 0 & 40 & 0 \\
\hline & 0.5 & 20 & $20(+)$ & 0 & 0 & 20 \\
\hline & 2 & 0 & 20 & 40 & 0 & 0 \\
\hline & 5 & 20 & 0 & 0 & 0 & 0 \\
\hline & 10 & 0 & 0 & 20 & 0 & 0 \\
\hline Spearmint & 0 & 0 & 0 & 20 & 0 & 0 \\
\hline & 0.5 & 0 & 20 & 0 & 0 & 0 \\
\hline & 2 & 20 & 20 & 20 & 20 & 0 \\
\hline & 5 & 0 & 0 & 20 & 0 & 0 \\
\hline & 10 & 0 & 0 & 20 & 0 & 0 \\
\hline & \multicolumn{6}{|c|}{ Hypocotyls } \\
\hline Peppermint & 0 & 0 & 0 & 0 & 0 & 0 \\
\hline & 0.5 & 0 & 0 & 20 & 20 & 20 \\
\hline & 2 & 20 & 20 & 20 & 0 & 0 \\
\hline & 5 & 0 & 40 & 20 & 0 & 0 \\
\hline & 10 & 20 & 40 & 20 & 20 & 0 \\
\hline \multirow[t]{5}{*}{ Spearmint } & 0 & 0 & 20 & 20 & 0 & 0 \\
\hline & 0.5 & 0 & 20 & 20 & 20 & 0 \\
\hline & 2 & 20 & 0 & 20 & 20 & 0 \\
\hline & 5 & 0 & 20 & 20 & 0 & 0 \\
\hline & 10 & 20 & 20 & 20 & 0 & 0 \\
\hline
\end{tabular}

${ }^{2}$ Percent of explants with callus $(\mathrm{n}=10$, except $\mathrm{n}=15$ where indicated with $*)$.

$y(+)=$ roots were formed.

Mature embryos and flower parts of peppermint and seedling parts of peppermint and spearmint were cultured on basal medium supplemented with $\mathrm{CW}\left(150 \mathrm{ml} \cdot \mathrm{liter}^{-1}\right)$ and the growth regulators $2,4-\mathrm{D}$ and $\mathrm{BA}$ or zeatin, each at $0,0.5,2,5,10 \mathrm{mg} \cdot \mathrm{liter}^{-1}$ in 5 $\times 5$ factorial experiments. Percent callus initiated on flower parts ranked as follows: petal $>$ ovary > anther > stigma (Table 2). Ovaries produced callus on medium without growth regulators. Cotyledons and hypoco- tyls of peppermint and spearmint were poor producers of callus and callus was not initiated" on root explants (data not shown). Callus initiated on medium containing 2,4D was creamy white, noncompact, and nonregenerative. Replacing BA with zeatin did not produce regenerants from mature embryo callus of peppermint or spearmint (data not shown).

Immature peppermint embryos 10 and 18 to $21 \mathrm{DAA}$ were chilled at $5 \mathrm{C}$ for 0.6 and 2 days, then cultured on basal medium containing NAA $\left(0.5,1,2,4 \mathrm{mg} \cdot\right.$ liter $\left.^{-1}\right)$. Embryos 10 DAA were transparent and 0.25 mm long. Embryos 18 to 21 DAA were opaque and were from 0.5 to $0.75 \mathrm{~mm}$ long. A higher percentage of embryos at 18 to 21 DAA $(22 \%)$ than at 10 DAA $(3 \%)$ initiated callus. There appeared to be no difference in percent callus production between $0.6(11 \%)$ and $2(8 \%)$ days of chilling.

Immature peppermint embryos were either nonchilled (15 to 18 DAA) or pretreated (12 to $26 \mathrm{DAA}$ ) by chilling at $5 \mathrm{C}$ or desiccating at room temperature $(\approx 23 \mathrm{C})$ for $0,0.6,2$, 4,5 , or 7 days. After pretreatment, embryos were cultured on basal medium supplemented with BA $\left(0,1 \mathrm{mg} \cdot \mathrm{liter}^{-1}\right)$, TIBA $(0$, $0.5,1 \mathrm{mg} \cdot$ liter $\left.^{-1}\right)$, adenine sulfate $(0,10$ $\left.\mathrm{mg} \cdot \mathrm{liter}^{-1}\right)$ and/or CW (0, $\left.150 \mathrm{ml} \cdot \mathrm{liter}^{-1}\right)$. All embryos were opaque and were from 0.4 to $1.0 \mathrm{~mm}$ long. Peppermint callus was initiated from chilled embryos, except on medium containing $10 \mathrm{mg}$ adenine sulfate/liter (Table 3). Plantlets regenerated from peppermint callus initiated from a nonchilled 15 to 18 DAA embryo and from a chilled (0.6 day) 16 to 20 DAA embryo on basal medium supplemented with $1 \mathrm{mg} \mathrm{BA}$ and $1 \mathrm{mg}$ TIBA/ liter (Fig. 1). Only 2\% (3/127) of the embryos desiccated before culture initiated callus (data not shown).

Preliminary experiments determined that a MS-based medium containing 2,4-D and $\mathrm{CW}$ produced nonregenerative mint callus that was creamy white and noncompact. However, another member of the Labiatae, Leucosceptrum canum, initiated regenerative callus on medium containing 2,4-D (0.5 $\mathrm{mg} \cdot$ liter $^{-1}$ ) and CW (150 ml-liter ${ }^{-1}$, (Pal et al., 1985).

Regeneration from peppermint callus occurred when initiated from mature embryos cultured on basal medium containing BA $(0.5$ $\mathrm{mg} \cdot$ liter $^{-1}$ ) and NAA (0.5 mg.liter ${ }^{-1}$ ) (Table 1) or from immature embryos on basal medium containing BA (1 mg.liter $\left.{ }^{-1}\right)$ and TIBA (1 mg.liter ${ }^{-1}$ ) (Table 3). Regenerative mint callus was creamy in color and compact. Callus of $L$. canum became organogenic when cultured on medium containing BA (2.5 $\mathrm{mg} \cdot$ liter $^{-1}$ ) alone (Pal et al., 1985). And budding from callus cultures of $M$. arvensis var. piperascens occurred on medium supplemented with NAA (1 mg.liter $\left.{ }^{-1}\right)$ and kinetin $\left(1 \mathrm{mg} \cdot\right.$ liter $\left.^{-1}\right)$ (One, 1982)

Explant source from various species has been shown to affect regeneration (Pierik, 1987). With mint, the only explants to initiate regenerative callus were mature and immature embryos (Tables 1 and 3).

Increased morphogenic capacity has been associated with chilling (Rangaswamy, 1986) or desiccation (Bouniols and Margara, 1968). While immature mint embryos that were chilled produced callus that was regenerative, only $2 \%$ of the desiccated embryos initiated callus.

The only mint to regenerate in this study was peppermint. This genotype-dependent regeneration may be due to either differences in genetic control of morphogenesis (Baronecelli et al., 1974) or to the tissue type of 
Table 3. Effect of BA, TIBA, adenine sulfate, coconut water (mg.liter ${ }^{-1}$ ), chilling time (SC), and embryo age on regeneration from immature embryos of peppermint.

\begin{tabular}{|c|c|c|c|c|c|c|c|}
\hline BA & TIBA & $\begin{array}{c}\text { Adenine } \\
\text { sulfate }\end{array}$ & $\mathrm{CW}$ & $\begin{array}{c}\text { Chilling }^{2} \\
\text { (days) }\end{array}$ & $\begin{array}{c}\text { Embryo age } \\
\text { (days) }\end{array}$ & $\mathrm{n}^{\mathrm{y}}$ & $\begin{array}{c}\text { Callus' } \\
(\%)\end{array}$ \\
\hline 0 & 0 & 0 & 150 & $\begin{array}{l}0 \\
0.6 \\
>2\end{array}$ & $\begin{array}{l}15-18 \\
12-26 \\
12-20\end{array}$ & $\begin{array}{r}4 \\
34 \\
19\end{array}$ & $\begin{array}{r}0 \\
26 \\
9\end{array}$ \\
\hline 0 & 1 & 0 & 150 & $\begin{array}{l}0 \\
0.6 \\
>2\end{array}$ & $\begin{array}{l}15-18 \\
12-26 \\
12-20\end{array}$ & $\begin{array}{r}4 \\
21 \\
17\end{array}$ & $\begin{array}{r}25 \\
43 \\
0\end{array}$ \\
\hline 0 & 0.5 & 0 & 150 & $\begin{array}{l}0 \\
0.6 \\
>2\end{array}$ & $\begin{array}{l}15-18 \\
12-26 \\
12-20\end{array}$ & $\begin{array}{r}5 \\
29 \\
21\end{array}$ & $\begin{array}{r}0 \\
31 \\
33\end{array}$ \\
\hline 1 & 1 & 0 & 0 & $\begin{array}{l}0 \\
0.6 \\
>2\end{array}$ & $\begin{array}{l}15-18 \\
12-26 \\
12-20\end{array}$ & $\begin{array}{l}2^{\mathrm{w}} \\
18^{\mathrm{w}} \\
19\end{array}$ & $\begin{array}{l}50 \\
22 \\
21\end{array}$ \\
\hline 0 & 0 & 10 & 0 & $\begin{array}{l}0 \\
0.6 \\
>2\end{array}$ & $\begin{array}{l}15-18 \\
12-26 \\
12-20\end{array}$ & $\begin{array}{l}2 \\
23 \\
15\end{array}$ & $\begin{array}{r}0 \\
0 \\
0\end{array}$ \\
\hline
\end{tabular}

$>2$ days of chilling includes those embryos chilled 2, 4, 5, or 7 days.

Number of embryos cultured, up to five per petri dish.

${ }^{x}$ Percent of embryos with callus.

'One embryo regenerated shoots.

the explants examined.

This preliminary research demonstrates that mints can be regenerated in vitro; however, additional factors must be investigated to improve regeneration if tissue culture techniques are to be used for the improvement of commercial-mints. expérimentales sur la néoformation de bourgeons inflorescentiels on végétatifs in vitro à partir d' explantats d' endive (Cichotium intybus L.) VI. Mise en évidence de l'influence de l'hydratation tissus. Ann. Physiol. Vég. 10:6981.

Green, R. J., Jr. 1985. Peppermint and spearmint production in the midwest. The Herb, Spice and Medicinal Dig. 3:1-5.

Green, R.J., Jr. 1987. Peppermint and spearmint production in the midwestem states, p. 40-42. In: J.E. Simon and L. Grant (eds.). Second Nat]. Herb Growing and Mktg. Conf. Proc. Purdue Res. Foundation, West Lafayette, Ind.

Murashige, T. and F. Skoog. 1962. A revised medium for rapid growth and bio-assays with tobacco tissue cultures. Physiol. Plant. 15:473497.

One, S. 1982. Studies on the improvement of the components of essential oil of genus Mentha by radiation. VIII Intl. Congr. Essential Oils. Oct. 12-17, 1980:80-84.

Pal, A., A. Banerjee, and K. Dhar. 1985. In vitro organogenesis and somatic embryogenesis from leaf explants of Leucosceptum canum Sm. Plant Cell Rpt. 4:281-284.

Pierik, R.L.M. 1987. In vitro culture of higher plants. Martinus Nijhoff, Boston.

Rangaswamy, N.S. 1986. Somatic embryogenesis in angiosperm cell tissue and organ cultures. Proc. Indian Acad. Sci. (Plant Sci.) 96:247271.

Baronecelli, S., M. Buiatti, A. Bennici, and M. Pagliai. 1974. Genetics of growth and differentiation in vitro of Brassica oleracea var. botrytis. III. Genetic correlations and ontogenetic unity. Z. Pflanzenzucht. 72:275-282.

Bouniols, A. and J. Margara. 1968. Recherches
Reisch, B. 1983. Genetic variability in regenerated plants, p. 748-769. In: D.A. Evans, W.R. Sharp, P.V. Ammirato, and Y. Yamada (eds.). Handbook of plant cell culture. vol. 1. Techlan, New York. niques for propagation and breeding. Macmil- 